\title{
ANSERJ
}

Vol . 8, No. 2

Autumn / Automne 2017

pp. $5-23$

Canadian Journal of Nonprofit and Social Economy Research

Revue canadienne de recherche sur les OBSL et l'économie social

\section{Which Frameworks Are Appropriate to Study and Describe Philanthropic Foundations in Canada?}

\author{
Sylvain Lefèvre \& Jean-Marc Fontan \\ Université du Québec à Montréal
}

\begin{abstract}
The article answers a central question: which analytical framework would be most relevant to understanding the Canadian grantmaking foundation sector? To answer this question, the authors present the sector using the statistical information and analytical frameworks of the Canada Revenue Agency. Then they make his portrait detailing the roles taken, and sometimes formalized theoretically, by the foundations. Finally, in a third part, the authors make use of the three main theoretical frameworks that they have identified in the scientific literature to analyze the foundations. The authors conclude the article by analyzing the interrelations, theoretical and practical, of these three analysis grids.

\section{RÉSUMÉ}

L'article répond à une question centrale : quel cadre d'analyse serait le plus pertinent pour comprendre le secteur des fondations subventionnaires canadiennes? Afin de répondre à cette question, les auteurs présentent le secteur en utilisant les informations statistiques et cadres d'analyse de l'Agence du Revenu du Canada. Puis ils font son portrait en détaillant les rôles pris, et parfois formalisés théoriquement, par les fondations. Enfin, dans un troisième temps, les auteurs font usage des trois principaux cadres théoriques qu'ils ont recensés dans la littérature scientifique pour analyser les fondations. Les auteurs concluent l'article en analysant les interrelations, théoriques et pratiques, de ces trois grilles d'analyse.
\end{abstract}

KEYWORDS / MOTS CLÉS Canada; Foundations; History; Philanthropy / Canada; Foundations; Histoire; Philanthropie 


\section{Lefèvre \& Fontan (2017)}

\section{INTRODUCTION ${ }^{1}$}

The world of philanthropic foundations is very heterogeneous. Some operating and grantmaking foundations have dozens of employees, yet most have few or none. Some are intrinsically linked to a family, while others are fully institutionalized. Some view gifts primarily as charity, while others see them more as an investment. Some fund only one local structure, such as a hospital, while others maintain international networks and very diverse programs. How might one find the way out of this maze? To help clarify this portrait, the intent of this article is to present three approaches, or frameworks, to analyze the Canadian foundation sector: descriptive typologies, the plurality of the roles and modes of action of foundations, and theoretical perspectives.

However, before developing these three approaches, this article addresses an important normative issue. Indeed, the exercise of description is also an exercise of characterization. The term "qualification" integrates the component that is both descriptive-objective and normative-subjective of such an operation. Most of the work and existing data on the philanthropic foundation sector is based on American foundations. This is the case for three main reasons. One, foundations play a much greater role in the United States than in most other countries. Two, the major studies on the philanthropic sector were conducted in the United States. And three, the United States built and cultivated its foundations in a perspective derived from Tocqueville writings, and described as the "American model." A model in which a strong civil society is to compensate for a low degree of intervention by the state.

\section{AMERICAN BIAS}

The descriptive and theoretical tools developed for observing U.S. foundations, shaped significantly by the industrial, religious, and political history of American society and its unique origins and genesis (Hammack \& Anheier, 2013), have sometimes been used indiscriminately to characterize foundations in other countries. Diagnoses made in this way then tend to negatively perceive the "delay" in relation to the American model, or the imperfection of other situations in comparison with this benchmark. Efforts to overcome this alleged problem then include the use of tools (fiscal, economic, managerial) applied in the U.S. philanthropic sector to contexts that are generally very different from that of the United States.

Moreover, the normative component of the task of qualifying philanthropic sectors can be captured through terms such as "third sector," "nonprofit sector" or "independent sector." Far from being similar or interchangeable, these terms are social constructs with identifiable origins. According to research conducted by Peter D. Hall (1992), in the United States, the nonprofit sector took shape from the 1960 s to the 1980 s. A process during which three key players eventually emerged.

These key players were John D. Rockefeller III (he played a pivotal role in the industrial and philanthropic Rockefeller family empire), John William Gardner (a former president of the Carnegie Foundation and the United States secretary of health, education, and welfare under Lyndon Johnson), and Daniel P. Moynihan (a democratic senator of New York, member of several presidential administrations, and sociologist). These actors participated in the structuration of the non-profit sector (Hall, 1992). Subsequently, the organization the Independent Sector, founded in 1980, served as a common platform, as well as a tool for gaining tax adjustments, for defining who belongs to, or does not, the nonprofit sector (including debate around the inclusion or exclusion of churches), and for structuring specific knowledge of the nonprofit sector, "which could be shared among philanthropy professionals, volunteers, the IRS, the Census Bureau and the general public" (Zunz, 2012, p. 261).

In the United States, the philanthropic sector created the structures that studied its own activities, namely through learned societies, university programs, professorships, scholarships, and publishing houses. It is this rather unique double 


\section{Lefèvre \& Fontan (2017)}

hermeneutic (Giddens, 2012) that allows us today to measure the normative scope of the descriptive process without difficulty. In the United States, this is manifested in the rather sharp controversies within academia about the historiography of foundations (Karl, 1997; Hall, 1999; Friedman, 2003) and in the divisions between professional organizations with regard to defining, representing, and promoting "true" and "good" philanthropy (e.g., between the Independent Sector [2017], the Center for Effective Philanthropy [2014], and the National Committee for Responsive Philanthropy [2017]. To study philanthropy, professional organizations or academia are dependent on the way the philanthropic sector is classified by administrative authorities.

\section{ADMINISTRATIVE TYPOLOGIES}

\section{Tax classification in Canada}

To illustrate the normative reach of a description of the foundation sector, this article points to the statistical scenarios of the United States and Canada. In the United States, the philanthropic sector encompasses, in keeping with its image of being a dense and widespread network, nearly 65,000 private foundations and has been likened to a "thousand points of light" by President George H.W. Bush in a famous speech (Bush, 1989). It should also be noted that of these 65,000 foundations, 25 ( $0.00004 \%$ of the total) hold 25 percent of the sector's assets ${ }^{2}$ (Prewitt, 2007), suggesting an oligarchic distribution of power.

Before reporting the orders of magnitude of the Canadian philanthropic sector, the administrative typology that governs this space in Canada are presented. To begin, in order to benefit from tax privileges in Canada, foundations must be registered with the Canadian Revenue Agency (CRA) as a charity and obtain a charity number. And for this, the CRA proposes three categories: public foundation, private foundation, and charity.

In its glossary, the CRA (Canada, n.d.) defines these categories as follows:

\section{"Private Foundation}

it is established as a corporation or a trust;

it has only charitable purposes;

it carries on its own charitable activities and/or it funds other qualified donees, usually other registered charities;

$50 \%$ or more of its directors, trustees, or like officials do not deal with each other at arm's length; and/or more than $50 \%$ of its funding comes from a person or group of persons that control the charity in any way or make up more than $50 \%$ of the directors, trustees, or like officials of the charity."

\section{"Public Foundation:}

it is established as a corporation or a trust;

it has only charitable purposes;

it generally gives more than $50 \%$ of its income annually to other qualified donees, usually other registered charities, but it may carry out some of its own charitable activities;

more than $50 \%$ of its directors, trustees, or like officials deal with each other at arm's length; and

it generally receives its funding from a variety of arm's length donors." "Charitable organization:

it is established as a corporation, a trust, or under a constitution;

it has only charitable purposes;

it primarily carries on its own charitable activities; 


\section{Lefèvre \& Fontan (2017)}

it has more than $50 \%$ of its directors, trustees, or like officials dealing with each other at arm's length; and

it generally receives its funding from a variety of arm's length donors."

The two categories that are of interest here are the private and public foundations. Private foundations often have a family or entrepreneurial core, with their own endowments, while public foundations are structured around a board of directors and independent directors. Public foundations frequently organize fundraisers and are sometimes created to finance a particular institution (e.g., a hospital, museum, or university).

Beyond this administrative triptych, other categories have been forged by actors who shape the philanthropic sector, such as Imagine Canada and Philanthropic Foundations Canada. ${ }^{3}$ The notion of "community foundation," driven by an eponymous organization (Community Foundations of Canada, 2017), means pooling endowments to meet the needs of a community, often on a geographical basis. Sometimes the term "parallel foundation" refers to a foundation created to raise funds and finance a single organization (e.g., a museum or hospital) without distributing grants elsewhere.

\section{Orders of magnitude}

In Canada, the philanthropic sector can be divided into four areas according to whether the foundation has an endowment of less than CND $\$ 25,000$ (27.3\% of foundations), CND $\$ 25,000$ to CND $\$ 1$ million (46\% of foundations), CND $\$ 1$ million to CND\$100 million (26.2\% of foundations), or over CND\$100 million (0.5\%, 56 foundations) (Kryvoruchko, 2013).

A report published in September 2014 and conducted jointly by Imagine Canada and Philanthropic Foundations Canada has contributed to this understanding of foundations ${ }^{4}$ and provided key information. First, from 1994 to 2014, the number of private foundations increased by 76 percent, reaching 5,300 organizations, and public foundations increased by 69 percent, reaching 5,100 organizations. In total, 10,500 foundations had revenues of CND $\$ 10.9$ billion and held assets of about $\$ 46$ billion (see Table 1).

\section{Table 1: Private foundations and public foundations in Canada: Numbers and resources (2014)}

\begin{tabular}{|l|c|c|c|}
\hline Type of organization & $\begin{array}{c}\text { Number of organizations } \\
(2014)\end{array}$ & $\begin{array}{c}\text { Revenue (billion CND\$) } \\
2012\end{array}$ & $\begin{array}{c}\text { Total assets (billion CND\$) } \\
2012\end{array}$ \\
\hline Public foundations & 5,141 & 6.5 & 21.4 \\
\hline Private foundations & 5,315 & 4.4 & 24.8 \\
\hline
\end{tabular}

Source: Imagine Canada, Philanthropic Foundations Canada, 2014, p. 2

The report then focuses on the 150 largest grantmaking foundations. ${ }^{5}$ In 2012 , these accumulated CND $\$ 18.7$ billion in assets, representing three-quarters of all assets held by grantmaking foundations. Of these 150 foundations, 32 have been created since 2002 and represent 41 percent of the assets of the major foundations. Subject to a concentration of resources and the heterogeneity of the sector, the top six of the 150 foundations hold approximately 50 percent of total assets. By contrast, half of the 150 foundations total less than 6 percent of assets. For 10 years now, the total value of the assets of the 150 foundations has more than doubled, despite the crisis of 2008, which appeared to have a greater impact on the gifts of these foundations. Geographically, nearly three-quarters of the main foundations are located in Ontario (52\%) and Québec (21\%), where they hold 88 percent of total assets. The recent creation of the Chagnon 


\section{Lefèvre \& Fontan (2017)}

Foundation (2000) in Québec, and the MasterCard Foundation (2006) and the Li Ka Shing (Canada) Foundation (2005) in Ontario underscore this trend. The ranking of the top 10 foundations by value of assets illustrates this point, in addition to indicating the volatility of the assets for some of these foundations (see Table 2).

\section{Table 2: Top 10 grantmaking foundations in Canada according to the value of their assets (2012)}

\begin{tabular}{|l|l|c|c|c|l|}
\hline Foundation & \multicolumn{1}{|c|}{ Type } & $\begin{array}{c}\text { Assets } \\
\text { (million CND\$) } \\
\text { in 2012 }\end{array}$ & $\begin{array}{c}\text { Assets } \\
\text { (million CND\$) } \\
\text { in 2013 }\end{array}$ & Registered & Province \\
\hline The MasterCard Foundation & private & $4,916.5$ & $8,797.0$ & 2006 & Ontario \\
\hline Fondation Lucie et André Chagnon & private & $1,440.7$ & $1,642.8$ & 2000 & Québec \\
\hline Li Ka Shing (Canada) Foundation & private & 924.7 & 893.1 & 2005 & Ontario \\
\hline SickKids Foundation & public & 781.6 & 875.9 & 1973 & Ontario \\
\hline The Azrieli Foundation & public & 529.6 & $1,046.0$ & 1989 & Québec \\
\hline McConnell Foundation & private & 507.5 & 555.4 & $1967^{6}$ & Québec \\
\hline The Buckingham Charitable Foundation & private & 339.6 & 258.6 & 1999 & Ontario \\
\hline Fondation Marcelle et Jean Coutu & private & 298.2 & 544.6 & 1990 & Québec \\
\hline The Joseph Lebovic Charitable Foundation & private & 227.1 & 235.1 & 1977 & Ontario \\
\hline The W. Garfield Weston Foundation & private & 223.8 & 240.8 & 1987 & Ontario \\
\hline
\end{tabular}

Source: Imagine Canada, Philanthropic Foundations Canada, 2014, p. 23

The 150 largest foundations in Canada reported giving an estimated total of $\$ 966$ million in gifts in the year 2012. This represents three-fifths of gifts made by all grantgiving foundations. Thus, the concentration is lower with regard to gifts than with regard to assets. The eight foundations with the largest amounts of gifts accounted for more than a quarter of the total value of gifts made by the 150 . Moreover, in 2002 , four foundations made gifts totalling $\$ 380$ million, which corresponds to 39 percent of the total value of gifts made during that year. As for the fields of intervention of these gifts, education and research are pre-eminent, followed by social services and health. At the bottom of the list are the funding categories "sports and recreation," "law, advocacy, and politics," and "government bodies." In terms of geographical distribution as well as private foundations, Ontario takes the lion's share, as illustrated in the classification of the top 10 major foundations according to the value of gifts in 2012 (see Table 3). Further, half of the top-assets foundations were created in the last decade. Finally, a comparison with the gifts from 2013 serves to highlight the extreme volatility that donations are subject to from one year to the next. 
Table 3: Top 10 grantmaking foundations in Canada

by the value of gifts (2012)

\begin{tabular}{|l|c|c|c|c|}
\hline Foundation & Type & $\begin{array}{c}\text { Total gifts } \\
\text { (million \$) } \\
\text { in } 2012\end{array}$ & $\begin{array}{c}\text { Total gifts } \\
\text { (million \$) } \\
\text { in 2013 }\end{array}$ & Province \\
\hline RBC Foundation & private & 51.2 & 52.8 & Ontario \\
\hline Li Ka Shing (Canada) Foundation & private & 51.1 & 90.4 & Ontario \\
\hline The MasterCard Foundation & private & 49.0 & 105.6 & Ontario \\
\hline The Buckingham Charitable Foundation & private & 28.6 & 35 & Ontario \\
\hline Rayjo Charitable Trust & private & 24.8 & 11.5 & Ontario \\
\hline The W. Garfield Weston Foundation & private & 23.6 & 21.6 & Ontario \\
\hline The Peter Gilgan Foundation & private & 22.7 & 3.1 & Ontario \\
\hline Frank And Ellen Remai Foundation Inc. & private & 21.4 & 5.0 & Saskatchewan \\
\hline The Friedberg Charitable Foundation & private & 18.9 & 34.2 & Ontario \\
\hline Theanon Charitable Foundation & public & 18.3 & 0.7 & Ontario \\
\hline
\end{tabular}

Source: Imagine Canada, Philanthropic Foundations Canada, p. 28

\section{MODES OF OPERATION OF GRANTMAKING FOUNDATIONS}

The various ways in which foundations present themselves on the Canada Revenue Agency website are indicative of distinct positioning. Some have very specific thematic orientations as to the allocation of their grants, while others are content to present very general and vague principles. Some give detailed information about their application processes, modalities to follow, and timetables for submitting a project. Others make it clear that they do not wish to be canvassed. Still others merely state that organizations looking for support should contact the foundation. Different types of philanthropic relationships between foundations and funded organizations can therefore be envisaged. For Peter Frumkin (2010), four ideal types exist (see Table 4).

\section{Table 4: Donor involvement}

\begin{tabular}{|l|l|l|l|}
\hline \multicolumn{2}{|c|}{} & \multicolumn{2}{l|}{ Level of congruence of values between donor and recipient } \\
\cline { 3 - 4 } & Weak & Strong \\
\hline $\begin{array}{l}\text { Engagement of donor with } \\
\text { recipient }\end{array}$ & Weak & Contractual relationship & Delegating relationship \\
\cline { 2 - 4 } & Strong & Audit relationship & Collaborative relationship \\
\hline
\end{tabular}

Source: Frumkin, 2010, p. 83 


\section{Lefèvre \& Fontan (2017)}

The involvement of the donor with the recipient depends primarily on the structure of the foundation. Some are professionalized and can afford a handful of salaried staff, yet most must make do without any paid employees. The involvement also depends on the understanding of the role of the foundation. Some foundations, once established with a well-defined action program and set of values and goals, hire third parties to carry out a given project. Yet others cover very large thematic areas without defining a specific focus or strategy. The former, it seems, are generally more active than the latter. Exceptions to this rule usually pertain to the issue of the autonomy given to the funded organizations, which also depends on the level of the organization and the potential heteronomy of the funded actors. For example, in Québec, foundations wishing to work with the community sector would do well to first examine the degree to which that sector is attached to its autonomy.

However, the involvement of the foundation also depends on whether the directors of the foundation have a "keep your hands on the wheel" approach with regard to the method of intervention, management, and partnership dynamics. Some foundations view grant allocation as being the core component, if not the main mission, of their work, and accordingly seek to structure themselves around a board of directors or project selection committee rather than a team of salaried staff. Other foundations, by contrast, see their actions as a continuum, ranging from the determination of priorities to the assessment of the impacts of projects, which includes fundraising, especially for public foundations, supporting partner organizations, or lobbying other stakeholders. In such a context where the allocation of grants is just one of several tasks, the foundation generally needs paid staff. Support to and evaluation of the funded organizations can be conducted by external providers, which would be paid on a project basis for tasks such as audit assignments.

This concept of the role of the foundation is also linked to the types of action being considered. A distinction is often made between donor foundations (grant giving), those who conduct their own programs (operation), and those that do both (mixed). Building on this triptych, Francie Ostrower (2006) developed a distinction with four dimensions. The first constitutes a proactive orientation whereby foundations take a leadership role in assessing the needs and problems to be addressed and in seeking and enlisting other organizations to collaborate in solving them. The second relates to technical support and capacity-building of funded organizations: this can happen, beyond the funding, through the training of the paid staff or the board of directors for targeted skills (e.g., strategic thinking, communication, and fundraising). The third dimension is the involvement of the foundation in advocacy to influence the design of social policies, and may include the lobbying of institutions, support for a collective action, and grants for specialized agencies on this mission (advocacy). The last dimension identified by Ostrower (2006) concerns the support of the foundation to its own paid staff, through continuous training on identified issues or on the processes of selection, assessment, and organizational support.

\section{Beyond raising funds: Philanthrocapitalism and the philanthropy of social change}

Among the particularly proactive foundations that are implementing these four dimensions, many question the traditionally assumed role of the foundation as a simple fundraiser. For some 15 years, approaches have been modelled to promote the active role of foundations within the spirit of "philanthrocapitalism," in the words of Matthew Bishop and Michael Green (2008). ${ }^{7}$

In philanthrocapitalism, two different phenomena converge. One is the transposition into the social sector of the logic of venture capitalism, with its focus on the leverage effect to maximize impacts, and of the support given to leaders and innovative practices, to be diffused to a broader scale. Specifically, this trend is manifested in the significant financial commitments made over the medium term (five years) as well as in rigorous monitoring and the construction of a tool for accountability, assessment, and specific goal setting (social return on investment [SROI] and the systematic benchmarking of best practices), with the goal of achieving structural change (Porter \& Kramer, 1999). A particular emphasis is placed on the process of the diffusion and expansion of the produced innovations, either through a pilot program that was tested, improved, and whose diffusion is supported, or by building strong organizations that, with stable revenues and structures, 


\section{Lefèvre \& Fontan (2017)}

are slowing becoming institutionalized. In short, the aim of this trend is to counteract long-time shortcomings in the philanthropic sector, among them: funding in piecemeal fashion, short-term projects, the lack of mission-based funding, no increase in capacity-building, and little adapted accountability.

The other phenomenon, or trend, converging in philanthrocapitalism is the promotion of the social investment paradigm (Jenson, 2012). This paradigm focuses on a targeted action against the root causes (e.g., education and early childhood) in order to prevent problems characterized by a more challenging scope and self-perpetuating logic (e.g., health problems, poverty, and violence). The metaphor of investment is used here in order to, rather than replicating a pilot project, work directly toward the spread of a project (up-scaling) through specific institutional structures or through franchise systems managed by social entrepreneurs (Frumkin, 2003). Frumkin (2003) points out that this polysemy of social investment is reflected in its joint use in the 1990s by both the U.S. Democratic Party and the entrepreneurs in Silicon Valley. In both cases, the aim was to adopt a more managerial (business-like) approach to address public issues. The success of this rhetoric of social investment at the political level—namely, invest today in root causes to avoid larger expenses later, and the transposition of managerial and financial tools into the social domain-from both sides allowed in North America, and internationally, for alliances between governments and foundations. Consider, as examples, the programs led by the Bill \& Melinda Gates Foundation or, at the Québec level, the Chagnon Foundation (Ducharme \& Lesemann, 2011). Yet, this model has been met with two lines of criticism. The first relates to the alleged novelty of the model and its rupture with the practices of older foundations (Katz, 2005). The second criticism is more about the divergence between the promises of the model and its achievements: relatively low sums of money committed, the questioning of the transfer of expertise and of the supposed superiority of management know-how, and the semantic inflation of the capacity to measure an impact (Frumkin, 2003).

However, among the foundations that consider themselves to have a strong commitment and to assume a role beyond the simple transfer of money, another trend can be identified: philanthropy for social change philanthropy. It shares some common traits with the previous trend - the promotion of the social investment paradigm—especially with regard to the limitations of the traditional philanthropic model. Sometimes it even proposes the same solutions as the previous trend, for example concerning the use, through financial policies on socially responsible investing, of foundation assets for the benefit of the designated causes. But for the rest, it is structurally opposed to the philanthrocapitalist approach.

In that context, an ideal type of philanthropy for social change, referred to as social change philanthropy or social movement philanthropy, was developed by Daniel Faber and Deborah McCarthy (2005). Here, foundations favour collective action aiming toward systematic or structural change, respecting the principle of self-determination of groups (grassroots), and working to increase the power to act (community empowerment). In other words, foundations are expected to remove the barriers to participation so that people can act for themselves and in their own name, and to promote advocacy strategies rather than compassionate charity or a predominant emphasis on prevention. Above all, it is less the amount of money that matters than how the grant is provided. This ideal type was inspired by the case study of the Haymarket People's Fund in Boston, where activists sit on the committee allocating funds, symbolically breaking with the distinction of the helped and those helping (Ostrander, 1995).

For Québec, we cite the case of the Fondation Béati, a private foundation created in 1990 with an anonymous donation from a person who is no longer involved in the governance. Characterized by a social as well as spiritual outlook, Fondation Béati pursues ambitious social justice objectives, including a protest and popular education component, and promotes a subversive interpretation of the Gospel that diverges from the ecclesiastical tradition and traditional pastoral practices. On its website, it presents itself in favour of "a state that plays its role of leader, regulator, legislator and redistributor of wealth. In particular, Fondation Béati emphasizes the structural causes of poverty and opposes any discourse and practice 


\section{Lefèvre \& Fontan (2017)}

that identifies the individual as solely responsible for his or her situation" (Fondation Béati, n.d., authors' translation). Besides the types of projects supported, we point to the foundation's approach to action. It does not present itself as a fundraiser but as an "accomplice" of the actors supported and whom it seeks to empower through specific support practices. This is manifested in the project selection committee, composed of representatives of the funded areas, and in the profiles of the project managers, who are closer to community organizations than to entrepreneurship or the financial world. In addition, Fondation Béati invests its assets according to the principles of socially responsible investing and uses a portion of assets (10\%) for solidarity loans related to its social mission.

This type of approach has received its share of criticism. First, authors have emphasized the very low quantitative weight of these types of foundations and their resources. For the United States, J. Craig Jenkins and Abigail Halcli (1999) observed that the budgets of social change initiatives have never been financed by more than one percent from grants from foundations, even from 1960 to 1970, when social movements (e.g., civil rights, peace, feminism, and environment) were more predominant. Second, foundations, or rather, foundation members and staff, are seen as being too close to the milieu they represent, thereby lacking an objective distance. These tensions come to the fore in particular in assessment and accountability exercises, which tend to reveal asymmetrical positions between funder and funded (Silver, 2007), especially in cases where the selection committee is composed of actors coming from the community sector. In that context, new tools must be created to make assessments that can reflect both formality and distance at once. In the absence of such a tool, the exercise, given the circularity of interrelations, eventually closes in on itself and results in values that leave little room for impromptu action or innovation.

\section{Political positioning}

Beyond technological choices and constraints concerning the administrative role, the means of action chosen by foundations may also reflect values and even political positions. In some countries, they may even have a direct link with party politics. For example, in Germany, all political parties have a correlating foundation (Stiftung): Konrad Adenauer Stiftung (CDU), Friedrich Ebert Stiftung (SPD), Friedrich Naumann Stiftung (FDP), Hanns Seidel Stiftung (CSU), Heinrich Böll Stiftung (Alliance 90/The Greens), and Rosa Luxemburg Stiftung (PDS). Most of these were created after the Second World War, in a context where many civic education programs were being developed, and are primarily financed with public funds on a pro rata basis of the party's representation in the Bundestag. These foundations have strong connections to not only local politics but also, and above all, to foreign policy, since they operate as quasi-nongovernmental organizations (NGOs) and are very involved internationally (Dakowska, 2014).

In contrast, organized philanthropy in the United States in the twentieth century evolved in a wholly unique social alchemy in which private actors (foundations) took on the responsibility of public issues, yet within a framework that prohibited any political activity. Political positioning was largely surreptitious and discreet, expressed rather with an affirmation of values or acquaintances with politicians, and with a guarded distance to the institutionalized political arena. Nevertheless, certain political trends can be identified in the philanthropic field. From 1960 to 1970, the major foundations were generally classified as liberal (in the American political sense), such as the Ford Foundation, which funded the development of women's studies and black studies, or the Carnegie and Rockefeller foundations. However, a network of conservative foundations also evolved during this time, in direct response to what was seen as a dangerous turn to the left by these large institutions. These then led to the creation of numerous think tanks that became very active starting in the 1980s and 1990s (e.g., the Heritage Foundation and the Cato Institute) in the neoliberal movement, alongside older but revived conservative foundations that were traditionally anti-government (e.g., the Pew Charitable Trusts and the Olin Foundation) (Zunz, 2012). In the 1970s, a network of progressive foundations also evolved from the left, having as their mouthpiece foundations such as the Chinook Fund (Denver), the Bread \& Roses Community Fund (Philadelphia), the Crossroads Fund (Chicago), the Vanguard Public Foundation (San Francisco), and the Haymarket People's Fund (Boston). This net- 


\section{Lefèvre \& Fontan (2017)}

work also included the Funding Exchange (Odendahl, 1990), founded in 1978 under the slogan "Change, not charity," which ceased operations in 2012. It should be noted that the budgets of these progressive foundations are much lower than those of the liberal and conservative foundations.

In Canada, there is not, strictly speaking, a political structuring of the philanthropic field, even if latent divides do exist between organizations with potentially conflicting values and methods. Nevertheless, a type of politicization can be observed. To begin, in a context where the Canadian government has cut funding to environmental groups and increasingly promoted fossil fuels, environmental foundations promoting sustainable development and the respect of international treaties (e.g., the Kyoto Protocol) may well appear to be protest-oriented, if not radical, while they had previously been perceived as fairly mainstream. At the same time, successive investigations by the Canada Revenue Agency have sought to determine whether registered charities spent less than 10 percent of their resources on political activities, as required by the Income Tax Act. Among the organizations audited were environmental organizations such as the David Suzuki Foundation, the Pembina Foundation, and the Tides Canada Foundation. ${ }^{8}$ Paradoxically, this incursion of political power in the philanthropic sphere leads to a form of politicization, in that foundations that had not been concerned by such issues to date are now positioning themselves in the debate.

As noted in the introduction, to reflect how researchers study foundations, we will look at the main theoretical approaches developed in the academic field over the last decades.

\section{THEORETICAL APPROACHES}

This analysis of a large and diverse body of academic research on foundations allows to distinguish between three main approaches: the liberal approach, the Gramscian approach, and interactions and circulations. ${ }^{9}$ The aim is not to trigger a dense historiographical debate but rather to allow for a better understanding of the divergences observed in this field of research and of the structural issues.

\section{Liberal approach}

The first approach refers to a research tradition that can be called liberal and that shares the original understanding of philanthropy as being about the well-being and progress of mankind and as being inherently defined by a form of disinterestedness, both in its moral (ethics and the generosity of "giving back," of a secular humanist or religious nature) and strategic dimensions. This last, strategic aspect refers to the notion that foundations, unlike governments or private enterprise, due to their independence, flexibility, and detachment from immediate needs, are able to develop a broader perspective as well as greater capacities to anticipate future challenges, to take risks and innovate, and to manoeuvre between and draw benefit from all institutional and governmental levels (from local to international). Similar to the pioneering work of Merle Curti and Roderick Nash (1965), works from this approach tend to have a hagiographic tone and to focus on the achievements of foundations in the fields of culture, research, and healthcare in the United States and abroad.

The term "liberal" also refers to a normative basis that legitimizes the role of foundations by embedding them in a political pluralism that feeds on the contributions of multiple actors. Their voices enrich the political debate and the solutions they propose contribute to the collective well-being. Many works, from the classic work of Robert Bremner (1960) to the most recent of Joel L. Fleishman (2007), contain historical and thematic panoramas illustrating the accomplishments of foundations that, at the same time, portray philanthropy as the embodiment of American culture alongside liberal democracy and the market economy.

Within this liberal analysis approach, the focus is often put on the initiative of the founding individuals and on their moral values, vision, and impact, unlike an analysis that focuses more on the configurations they are a product of and on the 


\section{Lefèvre \& Fontan (2017)}

structural and structuring contexts in which they are embedded. From a methodological point of view, this body of research often includes works that are based on the testimonies of the founders (e.g., in the French context, Seghers, 2009, and Gauthier \& Pache, 2014) and which are given the attributes of the Schumpeterian entrepreneur. The involvement of foundations is depicted as being beneficial by nature, and the aim is to unleash this energy, either by stimulating it or by suppressing cultural, fiscal, or administrative barriers that stand in its way.

The focus in the liberal analysis approach on the vision and aims of the foundation is also the result of a methodological phenomenon. Indeed, foundations have the specificity of being either very opaque organizations, committed only to minimal reporting beyond what is required by law, or of being active producers of knowledge in their own field, as pointed out in the introduction of this article. Thus, the wealth and quality of resources and services held by the great American foundations, notably in the form of archives, have been valuable assets to the work of researchers. Yet at the same time, since these resources were shaped and controlled by the main foundations, they invariably entailed a methodological bias for researchers (Tournès, 2008), who are generally unable to obtain comparable information resources from other actors (e.g., the funded organizations).

For some twenty years now, research on philanthropy has been undertaken by a sector of management sciences, parallel to social science research on the topic. In that context, countless guides have been produced on fundraising, ranging from the benchmarking of best practices for project support to change management and the promotion of new tools for impact analysis. At the interface of these two research disciplines, the work New Frontiers of Philanthropy, edited by Lester Salamon (2014), presents what appears to be a link between an analytical approach of macro-social transformations and a prescriptive approach of new philanthropic tools.

\section{Gramscian approach}

The second identifiable approach takes the opposite stance of the first. While the liberal movement dominated, especially in the decades following the Second World War, criticism of philanthropy began to circulate starting in the 1970s. Aside from a clear shift in tone, moving from hagiographic accounts to virulent denunciations, the methodology likewise changed.

To begin, this approach emerging in the 1970s actually reconnected with criticism brought forth in the first quarter of the twentieth century in the United States. Its principal argument is that the influence and power of foundations is illegitimate since they do not always play by the rules of democracy: governed by votes, elections, and political representation. The second argument is related to social class and contends that philanthropy is nothing other than a means for the wealthiest strata of society to maintain their domination over the whole of society, namely through the maintenance of an unequal social order, under the guise of defending consensual causes.

To this, the Gramscian perspective added yet another dimension in claiming that philanthropy simply replaces coercive force with the subtler but more determining power of cultural and intellectual hegemony. Several authors adopting this approach (Arnove, 1982; Berman, 1983; Fisher, 1983; Parmar, 2012; Roelofs, 2003) focused on the power of foundations as producers of knowledge, from applied research for practitioners to fundamental research in academia. A main example is the Rockefeller Foundation, which funds the structuring of the social sciences in the United States, including its integration within the state for purposes of social engineering (Fisher, 1983). Overall, works subscribed to the Gramscian approach are critical of the instrumentalization of academic knowledge and the social and political uses made thereof by philanthropic foundations.

Methodologically, the liberal and the Gramscian approaches are interested in the visions of the founder and the foundation programs only insofar as to show their normative bases, or their links to macro-structural socio-political issues. Counter to the common association of generosity and selflessness with philanthropy, these works reveal the forms of profit-sharing 


\section{Lefèvre \& Fontan (2017)}

and the circular flow of capital (economic, social, and cultural). In short, they dismiss or discredit any achievements by foundations as evidence of power and normativity. Further, some of these works reveal connections of philanthropy with adjacent fields (entrepreneurial, political, religious, and administrative), thereby discounting the alleged independence of the charitable sector. They also reveal the multipositionality of key actors, which is suggestive of the construction of a field of power. This latter stream of research is, in fact, no longer Gramscian but rather Bourdieuian, given its analyses in terms of capital and fields applied to the world of foundations (Dezalay \& Garth, 2002; Guilhot, 2004, 2006).

For yet another set of authors, this shift in focus toward the social uses of philanthropy by the elite means that, to put it bluntly, foundations do not serve to solve the problems of the poor but rather those of the rich (Anheier \& Leat, 2013; Odendahl, 1990). One long-time criticism levelled against foundations is that they are tax shelters and a means to maintain control over wealth. ${ }^{10}$ Yet here, philanthropy is also revealed as a tool for building a sense of nobility or distinction (Gousset, 2004) and for perpetuating a family dynasty (Marcus \& Dobkin Hall, 1992; Pinçon \& Pinçon-Charlot, 1996). Finally, it is a way to perform a duty, for philosophical, moral, or religious reasons, with terms in which the donor is fully in control, such as in the case of anonymous gifts, when the donor gives without being known and without being solicited thereafter (Schervish, 1994). This interpretation thus veers from the Gramscian approach, which presumes a form of consciousness and will to influence the social world as a motivation for any philanthropic initiative. Instead, it presupposes that foundations and donors exert, though often unconsciously, an indirect, secondary influence in the sense that they are constructing, cultivating, and maintaining a distinguished status in society for themselves.

\section{Circulations and interactions approach}

A third approach engages in an in-depth analysis of the influence of foundations by identifying the many complex interactions and circulations between foundations and funded organizations.

A first set of studies of this type revisited the questions posed by the Gramscian literature, by studying carefully the relationships between foundations and social movements in the United States from 1960 to 1970. Researchers (Jenkins \& Eckert, 1986; O'Connor, 2011) highlighted in particular the mollifying effect of foundation support to the African-American civil rights movement. For one, foundations gave the bulk of their support to the most moderate organizations and, second, they tended to "channel" racial anger through demands for professionalization, the promotion of less contestable means of confrontation (e.g., legal recourse), and institutional integration, which then stymied more straightforward forms of opposition. Thus, rather than the direct taking control of or the imposition of tactics or heteronomous goals by foundations, the latter initiated the relative depoliticization or even internalization, in the form of self-constraint, of these standards by the actors themselves. This diffuse influence was also found to occur when militant actors adopt instruments created by foundations, such as forms of certification in the case of the environmental movement (Bartley, 2007).

A number of studies also highlight the modalities of possible co-operations, more egalitarian than what the Gramscian perspective would concede to, between the fundraiser and the funded structure. This is the case with foundations working in the field of social change philanthropy presented above (Ostrander, 2005). For the environmental field, Deborah McCarthy (2004) highlighted how, within foundations, employees often have strong ties, and even past work experience, with the social movement, and subsequently a disposition to import the goals supported by these movements into the philanthropic sector. Far from being inert recipients, with the foundations pulling the strings from a distance, funded organizations are here portrayed as equal and active participants in the negotiation of this relationship and as developing their own positions and expertise on these issues (Incite!, 2007). ${ }^{11}$

From a theoretical point of view, progress was made when the focus shifted from the foundation, or the recipient, to the relationship between the two. Thus, in examining the global circulation of ideas, recent works pursue a more open per- 


\section{Lefèvre \& Fontan (2017)}

spective that seeks to detach itself from the alleged power of a given idea or author in order to focus on the roles of the translators and importers and on the dynamics of the appropriation, reception, and transformation of texts that exist beyond the contexts of production and reception (Saunier, 2004). Studying the role of fellows of the Rockefeller Foundation, Ludovic Tournès (2010) shows very well that, contrary to the idea of a simple "Americanization of Europe," we are also experiencing a return of the "Europeanization of America." From that perspective, foundations could be analyzed, beyond their financial role, as intermediaries between worlds whose meeting would have been unlikely otherwise, be it for geographical, administrative, political, or social reasons (Saunier \& Tournès, 2010). Methodologically, the application of this perspective requires, first, a description of the density of the operations of networking, appropriation, hybridization, and cross-fertilization of techniques, ideas, and structures (Gemelli \& MacLeod, 1998), and an examination of the role of intermediaries, brokers, and double agents (Guilhot, 2005) at the intersection of philanthropic social networks and plural social worlds. Compared with the clear-cut visions of the liberal-hagiographic or Gramscian-critical perspectives, this approach stands out for its attention to the subtle but determining differences of shifts and acculturations (Brison, 2005; Buxton, 2009). Then, still with regard to methodology, this focus on the relationship between the foundation and the recipient, leads to the consideration of philanthropy as a social relationship (Schervish \& Ostrander, 1990; Ostrander, 2007), whether between individuals or groups of actors. From a practical point of view, this could then enable different types of relationships. For example, some may be more favourable to the donor while others would give the recipient a certain degree of negotiating power and room to manoeuvre (Cloutier, 2011). However, the biggest challenge of this perspective lies with the formalization of the relationship in socio-political and economic contexts, characterized by fundamental asymmetries between foundations and funded agencies, and in particular when the aim is to render the relationship as egalitarian as possible (Duvoux, 2014; Eikenberry, 2006; Ostrander, 2007; Silver, 2006).

\section{CONCLUSION}

This article successively addresses three types of grids. The first pertains to the categories and indicators produced by the Canada Revenue Agency (level 1). It is used to count the foundations, classify them, and determine their assets and contributions. These indicators and categories constitute a shared ontology since they impose themselves institutionally across all foundations wishing to be recognized by the public authorities and to benefit from the privileged tax status of a foundation. Philanthropic actors and experts coproduced the second grid and it addresses the conceptualization of the role assumed by the foundations (level 2). Both descriptive and prescriptive, this conceptualization introduces ways of doing, generates reproducible reference frameworks, draws distinctions within the philanthropic field, and shows how new methods have supplanted older ones in the course of philanthropic history. Finally, researchers from academia produced the third analysis grid (level 3). This third grid outlines the specificities of the liberal, Gramscian, and interactions and circulations approaches, including their theoretical, methodological, and sometimes normative underpinnings, using the tripartition proposed by Tournès (2008).

Although the grids are presented side by side, for the sake of analytical clarity, it is crucial to consider the linkages among the three levels. The creation of indicators and official categories (level 1) generates the accountability and answerability of foundations and, therefore, the way in which they organize themselves and conceive their role (level 2). Thus, the definition of a legitimate perimeter of a foundation's action is constrained by what the CRA defines as charity or policy and by the funding caps envisaged for the second component. In turn, the emphasis placed by some foundations on the scale of their impact and on the ratio between their financial investments and any quantifiable results leads to the introduction of new indicators, sometimes formalized through specific methods (e.g., the social return on investment [SROI]). In that context, is it conceivable that some of these indicators developed by the philanthropic actors (level 2) might one day be resumed and institutionalized by the public authorities (level 1), whereby they would become a measure of accountability imposed on all foundations? Moreover, how should researchers deal with measures that are presented as being scientific, but whose concrete makeup is not amenable to being dealt with in a scientific manner? 


\section{Lefèvre \& Fontan (2017)}

Throughout this article, and starting with the introduction, we have also pointed out the sometimes complex enmeshment between the expertise generated by the philanthropic field (level 2) and the academic field (level 3). Analysis of the financial landscape of the philanthropic field is an important part of the academic research that is dedicated to it; while, in return, academic research serves as a theoretical basis for a part of organized philanthropy, offering it a vantage point and neutrality in relation to conflicts of value (Lefèvre, 2015). However, the links between academic research (level 3) and the production of official categories and indicators (level 1) are also important. For example, in Canada, the accountability constraints placed on foundations, together with the open access data on the CRA website on all registered foundations by researchers (and citizens), results in a wealth of information, yet nevertheless fails to elucidate certain areas. In that context, researchers are tempted to draw on data that is available and to refrain from investigating any areas that were neglected, as pointed out by Tournès (2008) in connection with the rich archives of a few large U.S. foundations. Indeed, these archives, while offering abundant and available material, are heavily determined and informed by a foundation's unique history. This explains, in part, why most of the research on foundations in fact concerns only a handful of large U.S. foundations and the recurring challenges they face. Given this strong focus on only the tip of the philanthropic iceberg, research thus risks being blinded to the bulk of the mass, which remains submerged under rather opaque water. In terms of the foundations that have thus been overlooked, we noted, for example, our near-total lack of knowledge of small foundations (with assets under $\$ 25,000$ ), which account for over a quarter of Canadian foundations.

With regard to the issues and challenges facing foundations, among the contributions of level 3 , the circulations and interactions analysis grid offers a new perspective for investigating the areas that were neglected by the level 1 and level 2 analysis grids. It does so by proposing a decentralization from the unique focus on foundations as organizations, or on the money flows that structure them. It suggests that studying the philanthropic relationship between the donor and the recipient, in all its structural ambivalence and beyond a proclaimed disinterestedness (liberal vision) or a denounced hegemony (Gramscian vision). It invites us to study this relationship from the point of view of not only the foundation but also of the funded organizations, and even, more generally, of other stakeholders participating in the "philanthropic ecosystem" (e.g., public authorities, private companies, trade unions, churches, social movements, etc.) (Levesque, 2014). Beyond its heuristic interest, this approach could serve to inform the level 1 and 2 analysis grids when revisiting the currently prevailing question of the effectiveness of foundations. Who or what "makes a difference," to use the consecrated term? The donor? The recipient? Their relationship? The relationships with stakeholders in conjunction with the donor-recipient pair? How would these stakeholders have to function within a broader environment (e.g., economic, political, or legal) such that this pair's action would be decisive or, conversely, incidental? Depending on the answer to this question, the categories of the accountability and objectification of the foundations' action (level 1) and the conceptualization that these foundations have of their own role (level 2) could be at stake.

\section{NOTES}

1. This article is a reworked version of a book chapter published in French: Sylvain Lefèvre and Irena Khrovrenkov (2017), "Regards croisés sur la classification des fondations: entre catégories formelles et constructions théoriques". This chapter contains a broader empirical description, thanks to the statistical data collected by Irina Khovrenkov.

2. Among them, the foundations Gates, Pew, Ford, Rockefeller, MacArthur, Lilly, Carnegie, and Hewlett.

3. For a comparison between the different typologies of the CRA, the PFC, or Imagine, see Chamberland, 2012.

4. This report combines the analyses of data related to the administrative filings made with the Charities Directorate of the Canada Revenue Agency and data about grantmakers and recipients contained in Imagine Canada's online Grant Connect database.

5. Therefore excluded are in particular "parallel foundations" (e.g., hospital foundations), foundations established to fund in perpetuity a defined group of donors, and foundations conducting their own charitable activities (see Imagine Canada, Philanthropic Foundations Canada, 2014). 


\section{Lefèvre \& Fontan (2017)}

6. The McConnell Foundation was created in 1937 and became The McConnell Family Foundation 30 years later, following the death of J.W. McConnell in 1963.

7. This term is an umbrella term for the many subtle differences that flourished over the last 20 years, among them venture philanthropy (Letts, Ryan, \& Grossman, 1997), strategic philanthropy (Porter \& Kramer 1999), effective philanthropy (Center for Effective Philanthropy, 2014), and high impact philanthropy.

8. Human rights organizations (e.g., Amnesty International) and humanitarian organizations were also targeted, such as OXFAM Canada, which was commanded by the CRA to review its mission if it wanted to remain registered, because "poverty reduction is charitable, but preventing it is not" (The Canadian Press, 2014).

9. We adopt a tripartite approach developed by Ludovic Tournès (2008). We thank the author for sending us the first chapter of his HDR (Habilitation à diriger des recherches) Dissertation, which is not yet published.

10. Historically, the oft-cited example is the Ford Foundation (Zunz, 2012), but other examples have recently made the news, as in the case of Dieter Schwartz, CEO of the German company Lidl, which enjoys the legal and fiscal structure of a charitable foundation to maintain control over its business empire.

11. Paradoxically, we also observe that there are rather few academic researches that conduct, in parallel, a self-analysis of their relationship with the foundations that fund their work, including those working on these foundations (OseiKofi, 2010).

\section{WEBSITES}

Azrieli Foundation, http://www.azrielifoundation.org/

Bill \& Melinda Gates Foundation, https://www.gatesfoundation.org/

Buckingham Charitable Foundation, https://www.buckinghamfoundationinc.org/

Fondation Béati, http://www.fondationbeati.org/

Fondation Lucie et André Chagnon, https://fondationchagnon.org/en/index.aspx

Li Ka Shing (Canada) Foundation, https://www.lksf.org/

Peter Gilgan Foundation, http://petergilganfoundation.org/

MasterCard Foundation, http://www.mastercardfdn.org/

McConnell Foundation, https://mcconnellfoundation.cal

Rockefeller Foundation, https://www.rockefellerfoundation.org/

SickKids Foundation, https://www.sickkidsfoundation.com/

W. Garfield Weston Foundation, http://www.westonfoundation.org/

\section{REFERENCES}

Anheier, H. \& Leat D. (2013). Philanthropic Foundations: What Rationales? Social Research, 80(2), 449-472.

Arnove, R. (1982). Philanthropy and cultural imperialism. The foundations at home and abroad. Bloomington, IN: Indiana University Press.

Bartley, T. (2007). How foundations shape social movements: The construction of an organizational field and the rise of forest certification. Social Problems, 54(3), 229-255.

Berman, E.H. (1983). The ideology of philanthropy: The influence of the Carnegie, Ford and Rockefeller foundations on American foreign policy. Albany, NY: State University of New York Press.

Bishop, M., \& Green, M. (2008). Philanthrocapitalism. How the rich can save the world. New York, NY: Bloomsbury Press.

Bremner, R. (1960). American philanthropy. Chicago, IL: University of Chicago Press.

Brison, J.D. (2005). Rockefeller, Carnegie, and Canada: American philanthropy and the arts and letters in Canada, Montreal, QC \& Kingston, ON: McGill-Queen's University Press. 


\section{Lefèvre \& Fontan (2017)}

Bush, G. (1989, January 20). Inaugural Address of the President of the United States. URL : http://www.bartleby.com 1124/pres63.html [September 22, 2014].

Buxton, W.J. (Ed). (2009). Patronizing the public: American philanthropy's transformation of culture, communication, and the humanities. Lexington, MA: Lexington Books.

Canada. (n.d.). Charities and giving glossary. Ottawa, ON: Canada Revenue Agency. URL: https://www.canada.ca /en/revenue-agency/services/charities-giving/charities/charities-giving-glossary.html [September 22, 2014].

Centre for Effective Philanthropy. (2014). Centre for effective philanthropy. URL: http://cep.org/ [November 15, 2016].

Chamberland, V., Gazzoli, P., Dumais, L., Jette, C., \& Vaillancourt, Y. (2012). Fondations et philanthropie au Canada et au Québec : influences, portraits et enjeux. Montréal, QC : Cahiers du LAREPPS, no 12-02, juillet.

Cloutier, C. (2011). Les organismes à but non lucratif : comment mieux gérer les relations avec les donateurs? Gestion, 4(36), 85-94.

Community Foundations of Canada. (2017). Community foundations of Canada. URL: http://communityfoundations.ca/ [November 12, 2017]

Curti, M. (1957). The history of American philanthropy as a field of research. American Historical Review, 62(2), 352-363.

Curti, M., \& Nash, R. (1965). Philanthropy in the shaping of American higher education. New Brunswick, NJ: Rutgers University Press.

Dakowska, D. (2014). Le pouvoir des fondations. Des acteurs de la politique étrangère allemande. Rennes, FR : Presses Universitaires de Rennes.

Dezalay, Y., \& Garth, B. (2002). La mondialisation des guerres de palais. Paris, FR : Editions Seuil.

Ducharme, É., \& Lesemann, F. (2011). Les fondations et la « nouvelle philanthropie » : un changement de paradigmes scientifiques et politiques. Lien social et Politiques, Numéro 65 (printemps), 203-224.

Duvoux, N. (2014). La philanthropie contre la pauvreté urbaine. Étude de cas à Boston. Revue française des affaires sociales, 1(1),144-168.

Eikenberry, A.M. (2006). Giving circles: Growing grassroots philanthropy. Nonprofit and Voluntary Sector Quarterly, 35(3), 517-532.

Faber, D. \& D. McCarthy. (2005). Introduction. In Faber D. \& McCarthy, D. (Eds.), Foundations for social change. Critical perspectives on philanthropy and popular movements (pp. 3-32). Lanham, MD: Rowman \& Littlefield.

Fisher, D. (1983). The role of philanthropic foundations in the reproduction and production of hegemony, the Rockefeller Foundation and the social sciences. Sociology, 17(2), 206-233.

Fleishman, J.L. (2007). The foundation. A great American secret: How private wealth is changing the world. New York, NY: Public Affairs.

Fondation Béati, (n.d.). Nos convictions. URL: http://www.fondationbeati.org/qui_nous_sommes/convictions.html [September 17, 2017].

Fondations philanthropiques Canada \& Imagine Canada. (2014). Actif et dons des fondations donatrices du Canada. Montréal, QC.

Friedman, L. (2003). Philanthropy in America: Historicism and its discontents, In L. Friedman and M. McGarvie (eds), Charity, Philanthropy and Civility in American History (pp. 1-21), Cambridge, Cambridge University Press.

Frumkin, P. (2003). Inside venture philanthropy. Society, 40(4), 7-15.

Frumkin, P. (2010). The essence of strategic giving. A practical guide for donors and fundraisers. Chicago, IL: The University of Chicago Press.

Gauthier, A., \& Pache, A.C. (2014). La philanthropie. Une affaire de familles. Paris, FR : Autrement.

Gemelli, G., \& MacLeod, R. (eds). (2003). American foundations in Europe: Grant-giving policies, cultural diplomacy and trans-atlantic relations, 1920-1980. Brussels, BE: Peter Lang.

Giddens, A. (2012). La constitution de la société. Paris, FR : Presses Universitaires de France. 


\section{Lefèvre \& Fontan (2017)}

Gousset, S. (2004). Sociabilités bourgeoises et investissements " philanthropiques » : une approche par les Clubs Rotary. Lille, FR : Université de Lille II, thèse de doctorat de science politique.

Guilhot, N. (2004). Une vocation philanthropique : George Soros, les sciences sociales et la régulation du marché mondial. Actes de la recherche en sciences sociales, 151-152(1), 36-48.

Guilhot, N. (2005). The democracy makers: Human rights and the politics of global order. New York, NY: Columbia University Press.

Guilhot, N. (2006). Financiers, philanthropes. Sociologie de Wall Street. Paris, FR : Raisons d'agir.

Hall, P.D. (1992). Inventing the nonprofit sector: Essays on philanthropy, voluntarism, and nonprofit organizations. Baltimore, MD: Johns Hopkins University Press.

Hall, P.D. (1999). The work of many hands: A response to Stanley N. Katz on the origins of the "serious study" of philanthropy. Voluntary Sector Quarterly, 28(4), 535-536.

Hammack, D.C., \& Anheier, H.K. (2013). A versatile American institution: The changing ideals and realities of philanthropic foundations. Washington, DC: Brookings Institution Press.

Incite! Women of color against violence. (Ed). (2007). The revolution will not be funded: Beyond the non-profit industrial complex. Cambridge, MA: South End Press.

Independent Sector. (2017). About. URL: http://www.independentsector.org/about/ [November 15, 2016].

Jenkins, C., \& Eckert, C. (1986). Channeling black insurgency: Elite patronage and professional social movement organizations in the development of black movement. American Sociological Review, 51(6), 812-829.

Jenkins, C., \& Halcli, A. (1999). Grassrooting the system? The development and impact of social movement philanthropy, 1953-1990. In E. Lagemann (Ed.), Philanthropic foundations: New scholarship, new possibilities (pp. 229-256). Bloomington, IN: Indiana University Press.

Jenson, J. (2012). A new politics for the social investment perspective: Objectives, instruments and areas of intervention in welfare regimes. In G. Bonoli \& Natali, D. (Eds.), The politics of the new welfare state (pp. 21-44). Oxford, UK: Oxford University Press.

Karl, B.D. (1997). The troublesome history of foundations. Reviews in American History, 25(4), 612-618.

Katz, S. (2005, June). What does it mean to say that philanthropy is "effective"? The philanthropists's new clothes. Proceedings of the American Philosophical Society, 149(2), 123-131.

Kryvoruchko, I. (2013). Three essays in public economics: Flat taxes, foundation operations and giving. PhD Dissertation. Hamilton, ON: McMaster University.

Lefèvre, S. (2015). Pour une approche sociopolitique de la philanthropie financière: plaidoyer pour un programme de recherché. Politiques et sociétés, 34(2), 61-85.

Lefèvre, S., \& Khrovrenkov I. (2017). Regards croisés sur la classification des fondations: entre catégories formelles et constructions théoriques. In J.-M. Fontan, P. Elson, \& S. Lefèvre (Eds), Les fondations philanthropiques. De nouveaux acteurs politiques?, pp. 87-120. Montréal, Presses de l'Université du Québec.

Letts, C.W., William, R., \& Grossman, A. (1997). Virtuous capital: What foundations can learn from venture capitalists. Harvard Business Review, 72(2), 36-44.

Levesque, B. (2014). Éléments de synthèse et perspectives d'avenir pour la philanthropie: un système et une culture plurielle. In Institut Mallet (Ed.). Actes du sommet. Culture philanthropique: visages et transformations (pp. 129-212), Québec: Institut Mallet.

Marcus, G.E., \& Dobkin Hall, P. (1992). Lives in trust: The fortunes of dynastic families in late twentieth-century America. Boulder, CO: Westview Press.

McCarthy, D. (2004). Environmental justice grantmaking: Elites and activists collaborate to transform philanthropy. Sociological Inquiry, 74(2), 250-270.

National Committee for Responsive Philanthropy. (2017). National committee for responsive philanthropy. URL: https://www.ncrp.org/ [November 15, 2016]. 


\section{Lefèvre \& Fontan (2017)}

O'Connor, A. (2011). Contradictions de la philanthropie libérale face aux mouvements sociaux. Lien social et Politiques, 65(printemps), 19-42.

Odendahl, T. (1990). Charity begins at home. Generosity and self-interest among the philanthropic elite. New York, NY: Basic Books.

Osei-Kofi, N. (2010). Coercition, possibility or context? Questioning the role of private foundations in American higher education. Discourse: Studies in the Cultural Politics of Education, 31(1), 17-28.

Ostrander, S. (1995). Money for change: Social movement philanthropy at Haymarket People's Fund. Philadelphia, PA: Temple University Press.

Ostrander, S. (2005). Legacy and promise for social justice funding: Charitable foundations and progressive social movements, past and present. In Faber D. \& McCarthy, D. (Eds.), Foundations for social change. Critical perspectives on philanthropy and popular movements (pp. 33-60). Lanham, MD: Rowman \& Littlefield.

Ostrander, S. (2007). The growth of donor control: Revisiting the social relations of philanthropy. Nonprofit and Voluntary Sector Quarterly, 36(2), 356-372.

Ostrower, F. (2006). Foundation approaches to effectiveness: A typology. Nonprofit and Voluntary Sector Quarterly, 35, 510-516.

Parmar, I. (2012). Foundation networks and American hegemony. European Journal of American studies, 7(1), 1-25.

Pinçon, M., \& Pinçon-Charlot, M. (1996). Grandes fortunes : dynasties familiales et formes de richesses en France. Paris, FR : Payot.

Porter, M., \& Kramer, M. (1999). Philanthropy's new agenda: Creating value. Harvard Business Review, 77(6), 121-130.

Prewitt, K. (2007). Les grandes fondations philanthropiques américaines : comment justifier leur pouvoir? In Dogan M.

\& Prewitt K. (Eds.), Fondations philanthropiques en Europe et aux Etats-Unis (pp. 19-41). Paris, FR : Éditions de la Maison des sciences de l'homme.

Roelofs, J. (2003). Foundations and public policy: The mask of pluralism. Albany, NY: State University of New York Press.

Salamon, L.M. (Ed). (2014). New frontiers of philanthropy. A guide to the new tools and new actors that are reshaping global philanthropy and social investing. New York, NY: Oxford University Press.

Saunier, P.Y. (2004). Circulations, connexions et espaces transnationaux. Genèses, 57 (décembre), 110-126.

Saunier, P.Y. \& Tournès, L. (2010), Rockefeller, Gillet, Lépine and Co.: une joint venture transatlantique à Lyon

(1918-1940), in Tournès, L. (Ed). L'argent de l'influence. Les fondations américaines et leurs réseaux européens

(pp. 64-83) Paris, Autrement « Mémoires/Culture ».

Schervish, P.G. (1994). The sound of one hand clapping: The case for and against anonymous giving. Voluntas, 5(1), 1-26.

Schervish, P., \& Ostrander, S. (1990). Giving and getting: Philanthropy as a social relation. In Critical issues in American philanthropy. Strengthening theory and practice (pp. 67-98). San Francisco, CA: Jossey-Bass.

Seghers, V. (2009). La nouvelle philanthropie. Paris, FR : Autrement.

Silver, I. (2006). Unequal partnerships: Beyond the rhetoric of philanthropic collaboration. New York, NY: Routledge.

Silver, I. (2007). Disentangling class from philanthropy: The double-edged sword of alternative giving. Critical Sociology, 33(3), 537-549.

Skocpol, T. (1997). The Tocqueville problem: Civic engagement in American democracy. Social Science History, 21(4), 455-479.

The Canadian Press (2014), 'Preventing poverty' not a valid goal for tax purposes, CRA tells Oxfam Canada, URL : http://www.cbc.ca/news/politics/preventing-poverty-not-a-valid-goal-for-tax-purposes-cra-tells-oxfam-canada1.2717774 [November 15, 2016].

Tournès, L. (2007). La fondation Rockefeller et la naissance de l'universalisme philanthropique Américain. Critique internationale, 2(35), 173-197.

Tournès, L. (2008). La philanthropie américaine et l'Europe. Contribution à une histoire transnationale de l'Américanisation. Habilitation à diriger des recherches, Université Paris-1 Panthéon-Sorbonne, 2, chapitre 1. 


\section{Lefèvre \& Fontan (2017)}

Tournès, L. (Ed). (2010). L'argent de l'influence. Les fondations américaines et leurs réseaux européens. Paris, Autrement « Mémoires/Culture ».

Zunz, O. (2012). La philanthropie en Amérique. Argent privé, affaires d'État. Paris, FR : Fayard.

\section{ABOUT THE AUTHORS / LES AUTEURS}

Sylvain Lefèvre, département de stratégie, responsabilité sociale et environnementale, Université du Québec à Montréal, PhiLab, associé au Centre de recherche sur les innovations sociales (CRISES). Email: lefevre.sylvain@uqam.ca .

Jean-Marc Fontan, département de sociologie, Université du Québec à Montréal, PhiLab, associé au Centre de recherche sur les innovations sociales (CRISES). Email: fontan.jean-marc@uqam.ca . 